\title{
Dropship dalam perpektif ekonomi Islam
}

\author{
Mujahidin ${ }^{1}$ \\ ${ }^{1}$ IAIN Palopo \\ mujahidin@iainpalopo.ac.id ${ }^{1}$
}

\begin{abstract}
Abstrak,
perkembangan teknologi yang semakin berkembang membuat para pakar fikih untuk menggali kembali kitab klasik untuk melihat relevansi akad-akad yang terdapat dalam buku klasik tersebut sesuai dengan masanya. Salah satau yang mengemuka sekarang ini adalah jual beli dengan sistem dropship jual beli dimana penjual menjual produk yang tidak dimiliki dan tidak memiliki persediaanya (stok barang). Penjual hanya bermodalkan sampel (contoh) dari barang milik supplier, biasanya berupa foto, yang kemudian dipasarkan kepada konsumen melalui medai sosial atau toko online, jika terjual maka penjual membeli barang dari supplier dengan meminta tolong kepada supplier untuk mengirimkan barangnya dengan atas nama penjual. Karena ini tidak kita dapatkan dalam jual beli yang dilakukan masa lampau tetapi ternyata ada akad yang mengindikasikan kebolehan menjual sesuatu yang tidak ada pada saat akad jual beli yaitu akad salam, maka dropship ini bisa dilakukan dengan memakai akad salam atau juga bisa menggunakan akad simsarah.
\end{abstract}

Keywords: Dropship, akad salam, akad simsarah, supplier.

\section{PENDAHULUAN}

Teknologi berbasis internet sudah tidak bisa dipisahkan dari kehidupan orang zaman sekarang. Semua dilakukan serba online, dari mulai belanja barang, beli makanan, bayar pulsa, tagihan listrik sampai naik ojek semuanya dilakukan semudah menjentikkan jempol di layar smartphone.

Kehidupan zaman sekarang bak kehidupan surgawi. Apapun yang terbersit dalam pikiran, hanya dengan membuka layar hp, semua akan menghampiri tanpa harus susah payah beranjak dari tempat duduk. Tidak heran kalau mal-mal makin sepi, sebab sekarang mal itu secara virtual sudah pindah ke layar smartphone setiap orang.

Bahkan belanja online bagi sebagian orang bukan lagi hanya sebuah kebutuhan tapi sudah menjadi tren dan gaya hidup. Saking asyiknya belanja online sehingga barang apapun dibeli walaupun mungkin tidak terlalu butuh. Ada kepuasan tersendiri ketika melihat barang yang hanya kita lihat gambarnya di layar hp tiba-tiba tanpa menunggu lama, barang itu secara nyata ada di hadapan kita.

Kemudahan itu ternyata tidak hanya berlaku bagi konsumen atau pembeli tetapi juga bagi orang yang berniat untuk berjualan. Di zaman sekarang ini orang yang ingin berjualan tidak harus memiliki lapak atau kios secara fisik. Bahkan tidak harus punya barang.

Ya, dengan cara dropshipping, seorang dropshipper hanya cukup bermodalkan data internet dan akun media sosial atau toko online dia sudah bisa Bahkan beberapa layanan marketplace seperti Tokopedia (htt), dan Bukalapak (htt1), pun kini sudah menyediakan fitur dropshipping bagi orang yang ingin berjualan tanpa modal. Cukup pasang foto barang di website atau di media sosial berikut deskripsinya, setelah itu tinggal menunggu orang yang memesan, 
kemudian pesanan itu disampaikan kepada supplier yang kemudian supplier akan mengirim barang yang dipesan langsung kepada pemesan tetapi dengan nama si dropshipper.

Sehingga dropshipper dalam hal ini benar-benar tidak banyak mengeluarkan effort. Tidak perlu kontrol stok barang, tidak perlu packing, tidak Perlu timbang, tidak perlu kontrol karyawan, tidak perlu bayar listrik air, tidak perlu bayar biaya gudang, bahkan tidak perlu capek-capek mengirim barang kepada pemesan karena barang dikirim oleh supplier.

Tapi muncul pertanyaan, apa hukumnya orang yang melakukan transaksi jual-beli padahal barangnya belum ada? Bukankah Islam melarang juaI-beli barang yang belum ada atau belum dimiliki? Apakah dengan demikian dropshipping haram hukumnya?

\section{HASIL DAN PEMBAHASAN}

A. Dropship

Dropshipping adalah suatu sistem jual beli dimana penjual menjual produk yang tidak dimiliki dan tidak memiliki persediaanya (stok barang). Penjual hanya bermodalkan sampel (contoh) dari barang milik supplier, biasanya berupa foto, yang kemudian dipasarkan kepada konsumen melalui medai sosial atau toko online, jika terjual maka penjual membeli barang dari supplier dengan meminta tolong kepada supplier untuk mengirimkan barangnya dengan atas nama penjual.

Dropship mirip dengan metode penjualan secara eceran, tetapi pihak pengecer yang tidak perlu menyimpan atau memiliki produk secara fisik. Pengecer tersebut yang kemudian disebut sebagai dropshiper (reseller dropship) bekerjasama dengan supplier yang akan memasok produk yang dijual oleh pihak dropshiper. Pihak supplier nantinya yang akan mengirim langsung kepada pembeli.

Mekanisme ini memang diminati oleh kalangan yang baru memulai usaha tapi terbatas dalam hal pengalaman dan minim modal, karena tidak perlu menggunakan modal besar dan risiko dalam sistem dropshipping ini relatif sangat kecil.

B. Skema Transaksi dengan Sistem Dropship

Berikut ini adalah salah-satu contoh skema transaksi online dengan sistem dropship: (Prabowo, Priyono, \& Dewi, 2016)

1. Dropshipper mengiklankan produk supplier ke berbagai media sosial atau toko online yang telah dibuat. Gambar-gambar dan keterangan yang berkaitan dengan produk yang di iklankan didapat dari pihak supplier.

2. Pembeli (konsumen) kemudian melihat iklan penjualan barang dari reseller dropship di berbagai media sosial.

3. Konsumen yang tertarik untuk membeli kemudian melakukan order (pesan) ke pihak reseller dropship. Setelah melakukan pemesanan barang pihak reseller dropship menanyakan ketersediaan barang yang dipesan konsumen kepada supplier. Setelah pihak konsumen dan reseller dropship sepakat melakukan transaksi kemudian konsumen mentransfer sejumlah uang yang telah disepakati kepada reseller dropship.

Setelah menerima pembayaran dari pihak konsumen, reseller dropship kemudian meneruskan pesanan barang ke pihak supplier dan mentransfer sejumlah harga barang yang dipesan konsumen ditambah dengan harga pengiriman barang. Setelah supplier menerima pembayaran dan pesanan barang dari pihak resellerdropship, maka pihak supplier kemudian memproses pesanan tersebut dengan melakukan pengepakan dan mengirimkan barang tersebut ke alamat konsumen dengan menggunakan jasa pengiriman. Di dalam paket pengiriman barang tersebut 
Volume 01 Nomor 02 Ed. Desember 2019 : page 140-149 p-ISSN: 2686-262X e-ISSN : 2685-9300

DOI : $\mathrm{xxxxxx}$

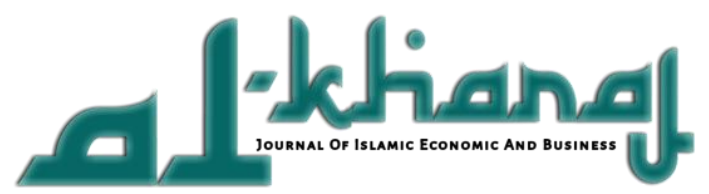

ditulis keterangan pengirim adalah pihak resellerdropship dan penerima adalah pihak konsumen disepakati kepada reseller dropship.

Setelah menerima pembayaran dari pihak konsumen, reseller dropship kemudian meneruskan pesanan barang ke pihak supplier dan mentransfer sejumlah harga barang yang dipesan konsumen ditambah dengan harga pengiriman barang. Setelah supplier menerima pembayaran dan pesanan barang dari pihak resellerdropship, maka pihak supplier kemudian memproses pesanan tersebut dengan melakukan pengepakan dan mengirimkan barang tersebut ke alamat konsumen dengan menggunakan jasa pengiriman. Di dalam paket pengiriman barang tersebut ditulis keterangan pengirim adalah pihak resellerdropship dan penerima adalah pihak konsumen.

C. Hukum menjual barang yang belum dimiliki

Seperti yang kita lihat dari skema di atas, masalah yang timbul dari transaksi dengan sistem dropship adalah bahwa ketika terjadi akad antara dropshipper dengan pembeli, dropshipper tidak memiliki objek barang yang diperjual-belikan. Apakah jual-beli seperti ini diperbolehkan oleh syariat?

Untuk menjawab pertanyaan itu, ada beberapa jenis akad dalam fiqih muamalah yang harus kita ketahui yang kemudian bisa kita tarik benang merahnya dengan jual-beli dropship ini.

1. Bai' al-Ma'dum

Bai' aI-Ma'dum secara bahasa artinya jual-beli barang yang tidak ada atau belum dimiliki. Artinya transaksi jual-beli sudah terjadi di mana penjual sudah menerima uang pembayaran dari pembeli, namun saat itu penjual belum memiliki objek barang yang diperjual-belikan, atau barang tersebut sudah dimiliki, hanya saja tidak bisa diserah-terimakan kepada pembeli, seperti jual-beli motor yang baru dicuri, atau burung yang lepas.

a. Dalil Bai' al-Ma'dum

Juai-beii semacam ini dilarang sebagaimana yang dipahami dari hadis berikut:

Rasulullah seseorang datang kepadaku meminta kepadaku untuk menjualkan barang yang tidak ada padaku, apakah aku boleh melakukan jual-beli itu kemudian baru aku beli barangnya di pasar?", Rasulullah SAW berkata, "Janganlah kau jual barang yang tidak ada padamu." (H.R. Tirmidzi, Abu Daud, Nasai, Ibnu Majah).

Dari hadis di atas secara sepintas kita bisa memahami bahwa menjual barang yang belum dimiliki hukumnya haram. Karena Nabi secara tegas melarang hal tersebut.

Akan tetapi ternyata para ulama tidak sesimpel itu dalam memahami hadis. Tidak mentangmentang Nabi melarang kemudian mengatakan semuanya haram.

b. Pendapat Ulama

Para ulama menyimpulkan kandungan hadis di atas dengan mengumpulkan dan membandingkan data-data yang diperoleh dari hadis-hadis yang lain. Bukan hanya bermodal satu atau dua hadis saja. Apalagi hadis terjemahan.

Bagaimana para ulama memahami hadis di atas? Sebutlah lbnu aI-Mundzir misalnya, sebagaimana

yang dinukil oleh Ibnu hajar dalam kitabnya Fathul Bari, beliau mengatakan:

Ibnu Mundzir berkata, "Bai' ma laisa 'indak mempunyai dua kemungkinan makna. Makna yang pertama adalah seseorang berkata aku jual kepadamu seorang budak atau sebuah rumah tertentu padahal tidak ada tidak terlihat. Hal ini mirip dengan jual beli gharar sebab mungkin saja budak atau rumah itu rusak yang menyebabkan pembeli tidak ridha. Yang kedua, seseorang berkata aku jual rumah ini seharga sekian sampai aku membelinya dari yang punya atau sampai yang punya menyerahkannya kepadamu. (al-'Asqolani, 1976)

Dari pernyataan Ibnu mundzir di atas dapat dipahami bahwa yang dimaksud dengan larangan juaI-beli barang yang belum dimiliki dalam hadis Hakim bin Hizam adalah sebagai berikut: 
Pertama, jual beli gharar, yaitu jual beli dengan informasi yang tidak jelas. Seperti yang dicontohkan oleh Ibnu Mundzir di atas, yaitu juaI-beli rumah tertentu, misalnya rumah tetangga saya, atau rumah di kampung A, akan tetapi rumah tersebut tidak diperlihatkan pada saat akad dan tidak dijelaskan informasi lengkapnya kepada pembeli. Sehingga hal ini dilarang karena menimbulkan potensi si pembeli merasa dicurangi atau ditipu.

Kedua, jual-beli barang milik orang lain tanpa seizin dari pemilik barang atau jual-beli barang yang tidak bisa dijamin apakah bisa diserahterimakan kepada pembeli atau tidak. lbnu Mundzir memberikan contoh seseorang menjual rumah yang bukan miliknya, kemudian setelah pembeli membayar, barulah si penjual meminta izin kepada pemilik rumah untuk menjualkan rumahnya. Ini tentu dilarang, karena bisa jadi pemilik rumah tidak mau menjual rumah itu padahal uang sudah di tangan penjual. Maka dalam contoh ini, rumah tersebut tidak bisa dijamin apakah bisa diserahkan kepada pembeli atau tidak.

Menurut lbnu hajar dari kedua penafsiran di atas, yang kedualah yang lebih relevan dengan hadis la tabi' ma laisa 'indak. Karena sama atau mirip dengan apa yang terjadi pada Hakim bin Hizam yang diceritakan dalam hadis.5

Imam as-Syaukani dalam kitabnya Nail al-Authar mengatakan bahwa yang dimaksud dengan ma laisa 'indak dalam hadis adalah barang yang tidak dalam kekuasaan seseorang walaupun barang itu adalah miliknya. Seperti menjual budak yang kabur dan burung yang lepas. (asySyaukani,, 1993)

Senada dengan asy-Syaukani, Imam asy-Syafi'i iuga memahami hal yang sama sebagaimana yang

dinukil oleh ar-Rafi'i dalam kitab Syarh Musnad asySyafi'i bahwa yang dilarang adalah juaIbeli barang tertentu dengan ketidak-jelasan baik informasi barangnya maupun bisa diserahterimakan atau tidak. (ar-Rafi'i, 2007)

Dari penjelasan ulama di atas, dapat disimpulkan bahwa larangan bai' al-ma'dum (juaI-beli barang yang tidak ada) letak poin keharamannya bukan karena barang itu tidak ada akan tetapi karena ada unsur gharar (ketidak-pastian) di dalamnya baik dari segi informasi barangnya atau kemungkinannya untuk diserahkan kepada pembeli. (ad-Dharir) Artinya jika barang itu tidak ada pada saat transaksi namun informasinya jelas dan dijamin bisa diserahkan kepada pembeli hukumnya boleh.

Seolah ketika Nabi mengatakan La tabi' ma laisa 'indak artinya adalah "Janganlah kamu jual barang yang tidak jelas atau barang yang tidak bisa diserahterimakan."

2. Bai' Salam

Jika dalam hadis Hakiim bin Hizam, Nabi melarang menjual barang yang belum dimiliki, menariknya di sisi lain Nabi justru membolehkan jual-beli salam, yaitu jual-beli di mana harganya dibayar di muka, akan tetapi barangnya diserahkan di kemudian waktu. Artinya, juaIbeli salam adalah juaI-beli barang

yang pada saat transaksi barangnya belum ada. Bukan hanya belum dimiliki tapi memang barangnya benar-benar belum ada.

a. Hukum Bai' Salam

Akan tetapi hampir semua ulama sepakat bahwa juaI-beli salam adalah juaI-beli yang diperbolehkan. Kecuali satu riwayat dari Said Ibn aI-Musayyib yang tidak memperbolehkan juaI-beli salam dengan berpegang kepada hadis Hakim bin Hizam.9 Selebihnya semua ulama sepakat akad salam adalah boleh.

JuaI-beli dengan akad salam ini merupakan kebiasaan yang dilakukan oleh orang-orang Madinah dalam juaI-beli kurma. Di mana orang-orang membeli kurma jauh hari sebelum kurma itu dipanen. Ketika Nabi hijrah ke Madinah Nabi membenarkan praktik jual-beli 
Volume 01 Nomor 02 Ed. Desember 2019 : page 140-149 p-ISSN: 2686-262X e-ISSN : 2685-9300

DOI : $\mathrm{xxxxxx}$

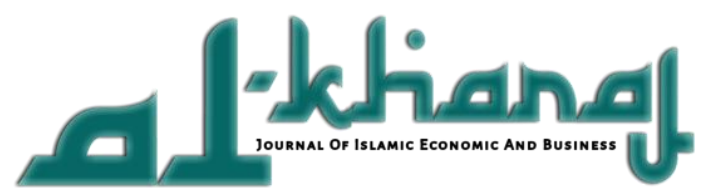

tersebut. Banyak hadis-hadis yang menunjukkan kebolehan jual-beli salam ini. Di antaranya beberapa hadis berikut.

b. Hadis-hadis Bai' Salam

Dari Ibnu Abbas r.a, ia berkata, "Katika Nabi datang ke Madinah, para sahabat terbiasa melakukan akad sa/am pada kurma dalam jangka waktu dua atau tiga tahun. Kemudian Nabi berkata, "Barang siapa yang melakukan akad sa/am pada sesuatu, maka hendaklah ia melakukannya dengan takaran yang jelas, berat yang jelas dan jangka waktu yang jelas."

Dari Ibnu Abbas ia berkata, "Nabi datang ke Madinah dan para sahabat mempraktekanjua/ beli salaf", Nabi pun berkata, "Barang siapa yang melakukan jual beli salaf janganlah ia lakukan kecuali dengan takaran dan berat yang jelas (pasti).” (HR. Ahmad: 2548)

Dari Nafi', dari Abdullah bin Umar, ia berkata, "Tidak masalah seseorang melakukanjual beli salaf dengan orang lain pada makanan yang sudah dijelaskan sifatnya dengan harga yang pasti sampai jangka waktu yang ditentukan. Selama jual beli tersebut bukan pada tanaman atau buahbuahan yang belum jelas baik atau jeleknya." (HR. Imam Malik: 2368)

Hadis-hadis di atas seakan bertentangan dengan hadis Hakim bin Hizam yang melarang jualbeli barang yang belum dimiliki. Untuk itu, para ulama kemudian memahami bahwa larangan juaI-beli barang yang belum ada atau dimiliki tidak mutlak adanya. Sebab dalam kasus juaIbeli salam Nabi memberikan pengecualian.

Pertanyaan berikutnya adalah apa perbedaan antara bai' al-ma'dum yang dilarang dengan juaIbeli salam?

3. Bai' al-Ma'dum Vs Bai' Salam

Kenapa Nabi melarang bai'al-ma'dum tetapi di sisi lain membolehkan Bai' Salam, padahal keduanya sama-sama menjual barang yang belum ada.

Ternyata ada perbedaan di antara keduanya. Jualbeli salam adalah jual-beli spesifikasi barang, bukan fisik barangnya. Sedangkan bai' al-ma'dum adalah jual-beli di mana sudah terjadi penentuan fisik barangnya, maksudnya ada penunjukan barang mana yang mau ditransaksikan. Sedangkan juaI-beli salam hanya terjadi penentuan sifat-sifat barang dan spesifikasinya saja. Tidak ada penunjukan barang.

Untuk lebih jelasnya penulis berikan dua ilustrasi yang menggambarkan bai' al-ma'dum yang dilarang dan bai'salam yang diperbolehkan.

Ilustrasi pertama:

A memesan beras kepada B yang merupakan seorang petani sekaligus pemilik sawah. A bilang kepada B saya beli hasil panen sawah milikmu ini, saya bayar sekarang seharga 2 juta. Panennya masih bulan depan.

Ilustrasi kedua:

A memesan beras kepada B. A bilang kepada B, saya pesan beras 2 kwintal untuk bulan depan. Saya bayar sekarang seharga 2 juta.

Adakah perbedaan dari dua kasus di atas? Yang mana yang haram dan mana yang halal?

Perbedaannya, pada ilustrasi pertama yang menjadi objek akadnya adalah hasil panen dari sawah tertentu. Sedangkan objek akadnya belum ada karena sawahnya baru bisa dipanen bulan depan. Di sini terjadi gharar atau ketidak-jelasan karena tidak ada yang tahu akan seberapa banyak hasil panen dari sawah tersebut. Bisa jadi panennya berhasil sehingga hasilnya sesuai dengan yang diharapkan pembeli, tetapi bisa juga panennya gagal sehingga pembeli dirugikan. Di sinilah letak keharamannya. Ada unsur ketidak-jelasan (gharar), bukan semata-mata karena beras itu belum ada pada saat transaksi.

Pada ilustrasi kedua, pembeli memesan beras dengan berat yang ditentukan yaitu dua kwintal. Pada saat jatuh tempo B harus menyerahkan beras sejumlah yang diminta oleh A. Andaikan 
hasil panennya tidak sesuai yang diharapkan, maka B tetap berkewajiban untuk menyerahkan beras kepada A sesuai jumlah yang dipesan. Maka pada kasus ini tidak ada unsur gharar sebab spesifikasi objek akadnya sudah disebutkan pada saat transaksi dan barang tersebut bisa diserah-terimakan kepada pembeli saatjatuh tempo.

D. Hukum Dropship

Setelah mengetahui perbedaan jual-beli barang yang belum dimiliki antara yang haram dan yang halal dan melihat skema yang terjadi pada transaksi jualbeli dengan sistem dropshipping. Dapat disimpulkan bahwa dropshipping hukumnya boleh.

Sebab dropshipping masuk ke dalam kategori jualbeli salam. Di mana pembeli memesan barang kepada dropshipper dengan spesifikasi tertentu, kemudian dropshipper meminta supplier untuk mengirimkan barang sesuai spesifikasi yang dipesan kepada pembeli.

Tetapi ada beberapa hal yang harus diperhatikan ketika melakukan dropshipping antara lain:

Pertama, Harga barang harus dibayarkan secara tunai pada saat transaksi. Untuk menghindari terjadinya juaI-beli hutang dengan hutang yang mana hal tersebut dilarang dalam hadis berikut: Dari Ibnu Umar bahwasanya Nabi Muhammad

SAW melarang jual beli hutang dengan hutang." (H.R. Ishaq dan al-bazzar).

Kedua, barang pesanan harus jelas jenis, bentuk, kadar, dan sifatnya. Karena itu menjadi syarat dalam jual-beli salam sebagaimana tertulis dalam hadis berikut:

Dari Abu al-Bakhtari at-Tha'i, ia berkata, "Aku bertanya kepada Ibnu Abbas r.a tentang jual beli salam pada kurma," ia pun berkata,"Nabi SAW melarang jual beli kurma sampai ditakar dan ditimbang. "

Juga hadis berikut:

Dari Ibnu Abbas ia berkata, "Nabi datang ke Madinah dan para sahabat mempraktekan jual beli salaf", Nabi pun berkata, "Barang siapa yang melakukan jual beli salaf janganlah ia lakukan kecuali dengan takaran dan berat yang jelas (pasti)." (HR. Ahmad: 2548)

Ketiga, barang pesanan dapat diserahkan begitu jatuh tempo penyerahan. Barang yang sulit diserahkan tidak boleh diperjual belikan, karena itu dilarang dalam akad salam.

Keempat, dropshipper harus selalu memantau stok barang yang ada di tangan supplier, jangan sampai ketika ada pembeli yang memesan, ternyata stoknya habis dan tidak bisa dikirimkan kepada pemesan. Untuk itu, sebaiknya seorang dropshipper tidak hanya bekerja sama dengan satu supplier saja, tapi dia juga harus punya backup supplier lain manakala stok barangnya habis, sehingga setiap saat bisa menjamin pemesan mendapatkan barang pesanannya tepat waktu.

E. syarat kebolehan Dropship

Dari dua cara akad di atas, maka jual beli dropship ini tidak melanggar ketentuan syariah. Meski kita sebagai penjual belum punya barangnya, dan modal kita cuma spek saja, tetapi syariat Islam membolehkan akad seperti ini. Akadnya bisa saja sebagai simsarah, atau broker. Mungkin yang agak mendekati adalah resaler. Berarti kita tidak membeli barang atau jasa, kita hanya membantu menjualkan barang atau jasa orang lain. Lalu kita mendapat fee dari tiap penjualan.

Atau akadnya bisa juga pakai akad kedua, yaitu akad salam. Pembeli membayar dulu kepada kita atas suatu barang atau jasa yang belum kita serahkan, bahkan belum kita miliki. Lalu uang pembayarannya itu baru kita belikan barang yang dimaksud, dan kita jualkan kepada si pembeli, dimana kita mendapatkan selisih harganya.

Kalau barang itu mau diatas-namakan milik kita juga boleh, karena kita memang benar-benar membeli dari sumbernya dan kita menjual kembali. Bahwa barang itu tidak sempat mampir ke tangan kita, tidak menjadi masalah. 
Volume 01 Nomor 02 Ed. Desember 2019 : page 140-149 p-ISSN: 2686-262X e-ISSN : 2685-9300

DOI : $\mathrm{xxxxxx}$

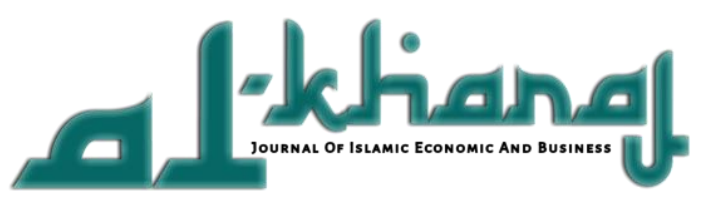

Toh, minyak kelapa sawit yang ada di hutan Kalimantan itu dijual ke berbagai negara lain (ekspor), tanpa harus mampir ke rumah pemiliknya. Siapa pemiliknya? Ya, wong londho yang ada di Belanda sana. Mereka cuma tahu bahwa rekening mereka tiap hari bertambah terus, tanpa pernah melihat sendiri kayak apa minyak kelapa sawit yang mereka perjual-belikan.

Hanya saja dalam akad salam ini, harus dipenuhi beberapa syarat dan ketentuan, antara lain :

Syarat Pada Barang

\section{Bukan Ain-nya Tapi Spesifikasinya}

Dalam akad salam, penjual tidak menjual ain suatu barang tertentu yang sudah ditetapkan, melainkan yang dijual adalah barang dengan spesifikasi tertentu.

Sebagai contoh, seorang pedagang material bangunan menjual secara salam 10 kantung semen dengan merek tertentu dan berat tertentu kepada seorang pelanggan. Kesepakatannya pembayaran dilakukuan saat ini juga, namun penyerahan semennya baru 2 bulan kemudian, terhitung sejak akad itu disepakati.

Walaupun saat itu mungkin saja si pedagang punya 10 kantung semen yang dimaksud di gudangnya, namun dalam akad salam, bukan berarti yang harus diserahkan adalah 10 kantung itu. Pedagang itu boleh saja dia menjual ke-10 kantung itu saat ini ke pembeli lain, asalkan nanti pada saat jatuh tempo 2 bulan kemudian, dia sanggup menyerahkan 10 kantung semen sesuai kesepakatan.

Sebab yang dijual bukan ke-10 kantung yang tersedia di gudang, tapi yang dijual adalah 10 kantung yang lain, yang mana saja, asalkan sesuai spesifikasi.

\section{Barang Jelas Spesifikasinya}

Barang yang dipesan harus dijelaskan spesifikasinya, baik kualitas mau pun juga kuantitas. Termasuk misalnya jenis, macam, warna, ukuran, dan spesifikasi lain. Pendeknya, setiap kriteria yang diinginkan harus ditetapkan dan dipahami oleh kedua-belah pihak, seakan-akan barang yang dimaksud ada di hadapan mereka berdua.

Dengan demikian, ketika penyerahan barang itu dijamin $100 \%$ tidak terjadi komplain dari kedua belah pihak.

Sedangkan barang yang tidak ditentukan kriterianya, tidak boleh diperjual-belikan dengan cara salam, karena akad itu termasuk akad gharar (untung-untungan) yang nyata-nyata dilarang dalam hadits berikut:

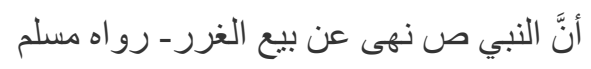

Nabi SAW jual-beli untung-untungan." (HR Muslim)

\section{Barang Tidak Diserahkan Saat Akad}

Apabila barang itu diserahkan tunai, maka tujuan utama dari salam malah tidak tercapai, yaitu untuk memberikan keleluasan kepada penjual untuk bekerja mendapatkan barang itu dalam tempo waktu tertentu.

Dalilnya adalah sabda Rasulullah SAW :

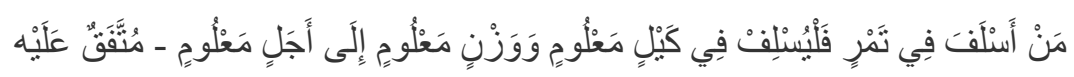


Siapa yang meminjamkan buah kurma maka harus meminjamkan dengan timbangan yang tertentu dan sampai pada masa yang tertentu’. (HR. Bukhari dan Muslim)

Al-Qadhi Ibnu Abdil Wahhab mengatakan bahwa salam itu adalah salaf, dimana akad itu memang sejak awal ditetapkan untuk pembayaran di awal dengan penyerahan barang belakangan.

\section{Batas Minimal Penyerahan Barang}

Al-Karkhi dari Al-Hanafiyah menyebutkan minimal jatuh tempo yang disepakati adalah setengah hari dan tidak boleh kurang dari itu.

Ibnu Abil Hakam mengatakan tidak mengapa bila jaraknya 1 hari.

Ibnu Wahab meriwayatkan dari Malik bahwa minimal jarak penyerahan barang adalah 2 atau 3 hari sejak akad dilakukan.

Ulama lain menyebutkan minimal batasnya adalah 3 hari, sebagai qiyas dari hukum khiyar syarat.

\section{Jelas Waktu Penyerahannya}

Harus ditetapkan di saat akad dilakukan tentang waktu (jatuh tempo) penyerahan barang. Hal ini berdasarkan sabda Rasulullah SAW :

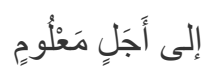

Hingga waktu (jatuh tempo) yang telah diketahui (oleh kedua belah pihak) pula." (Muttafaqun 'alaih)

Para fuqaha sepakat bila dalam suatu akad salam tidak ditetapkan waktu jatuh temponya, maka akad itu batal dan tidak sah. Dan ketidak-jelasan kapan jatuh tempo penyerahan barang itu akan membawa kedua-belah pihak ke dalam pertengkaran dan penzaliman atas sesama.

Jatuh tempo bisa ditetapkan dengan tanggal, bulan, atau tahun tertentu, atau dengan jumlah hari atau minggu atau bulan terhitung sejak disepakatinya akad salam itu.

\section{Dimungkinkan Untuk Diserahkan Pada Saatnya}

Pada saat menjalankan akad salam, kedua belah pihak diwajibkan untuk memperhitungkan ketersedian barang pada saat jatuh tempo. Persyaratan ini demi menghindarkan akad salam dari praktek tipu-menipu dan untung-untungan, yang keduanya nyata-nayata diharamkan dalam syari'at Islam.

Misalnya seseorang memesan buah musiman seperti durian atau mangga dengan perjanjian: "Barang harus diadakan pada selain waktu musim buah durian dan mangga", maka pemesanan seperti ini tidak dibenarkan. Selain mengandung unsur gharar (untung-untungan), akad semacam ini juga akan menyusahkan salah satu pihak. Padahal diantara prinsip dasar perniagaan dalam islam ialah "memudahkan", sebagaimana disebutkan pada hadits berikut:

$$
\text { لا ضَرَرَ ولا ضِرَار }
$$

Tidak ada kemadharatan atau pembalasan kemadhorotan dengan yang lebih besar dari perbuatan. (HR. Ahmad) 
Ditambah lagi pengabaian syarat tersedianya barang di pasaran pada saat jatuh tempo akan memancing terjadinya percekcokan dan perselisihan yang tercela. Padahal setiap perniagaan yang rentan menimbulkan percekcokan antara penjual dan pembeli pasti dilarang.

\section{Jelas Tempat Penyerahannya}

Yang dimaksud dengan barang yang terjamin adalah barang yang dipesan tidak ditentukan selain kriterianya. Adapun pengadaannya, maka diserahkan sepenuhnya kepada pengusaha, sehingga ia memiliki kebebasan dalam hal tersebut. Pengusaha berhak untuk mendatangkan barang dari ladang atau persedian yang telah ada, atau dengan membelinya dari orang lain.

Persyaratan ini bertujuan untuk menghindarkan akad salam dari unsur gharar (untunguntungan), sebab bisa saja kelak ketika jatuh tempo, pengusaha -dikarenakan suatu hal- tidak bisa mendatangkan barang dari ladangnya, atau dari perusahaannya. (Sarwat, t.thn.)

\section{KESIMPULAN}

Dari dua cara akad di atas, maka jual beli dropship ini tidak melanggar ketentuan syariah. Meski kita sebagai penjual belum punya barangnya, dan modal kita cuma spesfikasinya saja, tetapi syariat Islam membolehkan akad seperti ini. Akadnya bisa saja sebagai simsarah, atau broker. Mungkin yang agak mendekati adalah reseller. Berarti kita tidak membeli barang atau jasa, kita hanya membantu menjualkan barang atau jasa orang lain. Lalu kita mendapat fee dari tiap penjualan.

Atau akadnya bisa juga pakai akad kedua, yaitu akad salam. Pembeli membayar dulu kepada kita atas suatu barang atau jasa yang belum kita serahkan, bahkan belum kita miliki. Lalu uang pembayarannya itu baru kita belikan barang yang dimaksud, dan kita jualkan kepada si pembeli, dimana kita mendapatkan selisih harganya.

Kalau barang itu mau diatas-namakan milik kita juga boleh, karena kita memang benarbenar membeli dari sumbernya dan kita menjual kembali. Bahwa barang itu tidak sempat mampir ke tangan kita, tidak menjadi masalah. 


\section{DAFTAR PUSTAKA}

(n.d.). Retrieved from https://www.tokopedia.com/help/article/a-0650

(n.d.). Retrieved from https://www.bukalapak.com/bantuan/sebagai-pelapak/fitur-pelapaklainnya/dropshipper

ad-Dharir, S. (n.d.). Majallah al-Buhuts al-Islamiyah.

Agama, K. (2013). Al-Qur'an dan Terjemahnya. Bandung: CV Penerbit Diponegoro.

al-'Asqolani, I. h. (1976). Fathul Bari, Syarh Shahih al-Bukhari. Beirut: Darul Ma'rifah.

ar-Rafi'i, A. M. (2007). Syarh Musnad asySyafi'i . qatar: Kementerian Waqaf dan Urusan Agama.

asy-Syaukani,, M. A. (1993). Nail al-Authar. Mesir: Darul Hadits.

Gampito. (2008, juni). http://gampito.blogspot.co.id/. Retrieved from http://gampito.blogspot.co.id/: http://gampito.blogspot.co.id/2008/06/probematikaoperasionaliasi-bmt.html

Nasution. (1996). Metode Naturalistik Kualitatif. Bandung: Tarsito.

Prabowo, B., Priyono, E. A., \& Dewi, H. (2016). Tanggung Jawab Dropshiper Dalam Transaksi Ecommerce. Diponegoro law jurnal.

Pusat Inkubasi Bisnis Usaha Kecil.

Sarwat, A. (n.d.). Rumah Fiqih. Retrieved from Rumah Fiqih: https://www.rumahfiqih.com/x.php?id=1357202999

Suharsono, H. (2004). Bank dan Lembaga Keuangan Syariah. Yogyakarta: Ekonisia. 